\title{
Metacarpal Enlargement of the Amputated Thumb using Callotaxis: An Observational Study
}

\section{Alargamiento metacarpiano del pulgar amputado mediante callotaxis: estudio observacional}

\author{
Noemí Lambán-Mascaray ${ }^{1}$ Eduardo Blanco-Baiges ${ }^{2}$ \\ Samuel Pajares-Cabanillas ${ }^{5}$ Jesús Gómez-Vallejo ${ }^{2}$ \\ ${ }^{1}$ Orthopaedics and Traumatology Surgery, Hospital Royo Villanova, \\ Zaragoza, Spain \\ 2 Orthopaedics and Traumatology Surgery, Hospital Clínico \\ Universitario Lozano Blesa, Zaragoza, Spain \\ ${ }^{3}$ Hand Surgery, Hospital MAZ, Zaragoza, Spain \\ ${ }^{4}$ Orthopaedics and Traumatology Surgery, Hospital MAZ, \\ Zaragoza, Spain \\ ${ }^{5}$ Orthopaedics and Traumatology Surgery, Hospital Universitario \\ Fundación Jiménez Díaz, Madrid, Spain
}

Pedro Marquina-Sola ${ }^{3}$ Jesús Barco-Marcellán ${ }^{4}$

Address for correspondence Eduardo Blanco Baiges, MD, PhD, Traumatology and Orthopaedics, Hospital Clínico Universitario Lozano Blesa, avenida San Juan Bosco, Zaragoza, 50009, Spain (e-mail: edublanbai@gmail.com).

\begin{abstract}
Keywords

- bone lengthening

- callotaxis

- gradual distraction

- thumb amputation
\end{abstract}

Resumen
Purpose To confirm the effectiveness of bone elongation through callus distraction of the first metacarpal as a functional alternative in active patients with a thumb amputation.

Methods The study population consisted of patients who suffered a nonreplantable amputation of the thumb and failed to meet the criteria for a microsurgical transfer at our hospitals between 1995 and 2014. We performed an observational cohort study for the incidence analysis and a cross-sectional design for the analysis of the correlations among the variables.

Results We presented 23 callus distractions of the first metacarpal, with an elongation time between surgeries of approximately 104.7 days (standard deviation [SD]: 3.2), with a miniRail external mini-fixator, and an average elongation of $25.5 \mathrm{~mm}$ (SD: 0.54). All patients achieved a functional grip, but five of them had to find new jobs. The degree of satisfaction was high, except in two patients, and was significantly related to the time of the elongation.

Conclusions Callus distraction allows for a reconstruction of the thumb with few complications. We recommend associating it with a commissuroplasty and an adductor transposition. Patients give more importance to the comfort of the procedure than to the elongated length, provided that adequate function is achieved.

Objetivo confirmar la eficacia del alargamiento óseo mediante callotaxis del primer metacarpiano como alternativa funcional en pacientes activos con una amputación del pulgar, y revisar nuestros resultados. received March 14, 2017 accepted April 4, 2017
DOI https://doi.org/ 10.1055/s-0037-1602805. ISSN $1698-8396$.
Copyright @ $\odot 2017$ Thieme Revinter

Publicações Ltda, Rio de Janeiro, Brazil
License terms

(c) (i) $\ominus$ (\$) 


\author{
Palabras clave \\ - alargamiento óseo \\ - callotaxis \\ - distracción \\ progresiva \\ - amputación del \\ pulgar
}

Material y Método la población del estudio estuvo formada por pacientes que sufrieron una amputación no reimplantable del primer dedo de la mano, y que no cumplieron criterios para una transferencia microquirúrgica en nuestros centros hospitalarios desde el año 1995 hasta 2014. Se realizó un estudio observacional de cohortes para el análisis de incidencia y un diseño de corte trasverso para el análisis de correlaciones entre variables. Resultados presentamos 23 callotaxis del primer metacarpiano, un periodo medio de 104,7 días (SD) con un minifijador externo monorrail, y una elongación media de 25,5 milímetros (SD). Todos los pacientes consiguieron una pinza funcional, pero 5 tuvieron que cambiar de trabajo. El grado de satisfacción fue alto excepto en 2 pacientes, y se relacionó significativamente con la duración del alargamiento.

Conclusiones la callotaxis permite una reconstrucción del pulgar con pocas complicaciones. Recomendamos asociar una comisuroplastia y una transposición del aductor. Los pacientes dan más importancia a la comodidad del procedimiento que a la longitud alargada, siempre que se consiga una función adecuada.

\section{Introduction}

The thumb is the digit that sets us apart from other animals, including apes. The absence of a thumb, according to Spanish legislation, corresponds to a $40 \%$ level of disability of the affected hand, assuming that the amputation is located in the metacarpophalangeal joint. ${ }^{1}$ In fact, a thumbless hand requires the employee to be transferred to a different post or even be made redundant for medical reasons, with the associated financial implications, as well as the social and personal connotations that it will imply for the patient.

When faced with a patient with an amputated thumb, emergency replantation should always be the first option, although sometimes this is not feasible. In these cases, we have a choice between several reconstructive options that evolved during the 20th century: stump regularization is only valid in distal amputations, as are coverage or advancement flaps; ${ }^{2}$ the post-type osteoplastic thumb provides a rough thumb with little sensation; ${ }^{3}$ and thumb replacement sacrifices another healthy finger, and the hand loses grip. ${ }^{4,5}$ Currently, the technique of transferring a toe to the hand through vascular and nerve microstructures has given results closer to a healthy thumb, ${ }^{6}$ but this is a demanding technique that requires specific conditions, and sometimes cannot be performed. Factors affecting vascular permeability, such as tobacco consumption, diabetes, collagenopathies etc. worsen the prognosis of microvascular sutures, although they are not an absolute contraindication. ${ }^{7}$ The mechanism of the injury and the conditions of the tissues are determining factors. Avulsion injuries of the vasculonervous packages and softtissue fibrosis may hinder the prognosis for transferring a toe to the hand. And finally, sometimes patients, like those who are athletes, do not wish to lose a toe (due to aesthetic or personal reasons etc.), and prefer another technique. It is essential to explain the possible outcomes of the various surgical procedures to the patient.

The alternative we present here was described more than four decades ago by Matev, ${ }^{8}$ namely the lengthening of the thumb, which has been relegated to the background by the diffusion of modern microsurgical techniques. Within bone elongations, the technique of callus distraction of the thumb is a successful procedure, but the series of studies published performed with adults are scarce and heterogeneous. The importance of this study lies in the possibility of presenting results for the first time based on the incidence compared with previous publications on the subject.

The aim of this study is, once our results have been reviewed, to confirm the effectiveness of bone elongation through callus distraction of the first metacarpal as a functional alternative in active patients with non re-plantable thumb amputation, and to justify its use from a medical and occupational point of view.

\section{Materials and Methods}

Clinical design: this is an observational cohort study for incidence analysis with a cross-sectional design for the analysis of the correlations among variables.

The study population consisted of patients who suffered a non re-plantable amputation of the thumb and failed to meet the criteria for a microsurgical transfer at our hospitals between 1995 and 2014.

The inclusion criteria were as follows:

- Amputation of the thumb at levels II (through the proximal phalanx), III (through the metacarpophalangeal joint) and IV (through the metacarpal neck) of the Merle classification, ${ }^{9}$ preserving the thenar musculature.

- Emergency cases of non re-plantable thumbs.

- Thumb in which an emergency replantation was performed but subsequently failed.

- Rejection of microsurgical transfer of a toe to the hand for the following reasons: smoking, vascular diseases, age over 50 years, mechanism of injury for a vascular-nervous proximal avulsion or with major tissue destruction, and personal refusal of the patient to the transfer of a toe.

- Understanding and acceptance by the patient of the type of thumb reconstruction with respect to the other options. 
The standard surgical technique used was bone elongation of the first metacarpal using a MiniRail external fixator ${ }^{\circledR}$. (Orthofix, Verona, Italy) based on callus distraction with interventions and without bone graft insertion. In the first intervention, the doctors performed a subperiosteal osteotomy and implanted the external fixator, which was maintained for two weeks without distracting the focus, so that the fibrous callus could start to grow. Then, distraction began at a rate of $0.5-1 \mathrm{~mm}$ per day. When the desired length was reached and the radiology showed bone callus, it was maintained for two further weeks to relax the soft tissues, and the second intervention was performed, in which the fixator was removed, and adductor transposition and a commissuroplasty, if deemed necessary, were conducted. The minimum forecast elongation was set at $21 \mathrm{~mm}$. If in the second intervention the bone callus was found to be insufficient, a cortico-spongy or spongy graft was added, and the fixator was maintained, or percutaneous Kirschner needles were implanted until consolidation was achieved.

The transposition consisted of disinserting the adductor of the metacarpophalangeal joint and inserting it into the proximal $1 / 3$ of the metacarpal to extend the commissure and avoid excessive traction of the muscle, which could deform the bone callus.

The commissuroplasty was performed with a simple zplasty, or with a double-opposing z-plasty, or "jumping man" along the commissural cutaneous major axis, to increase the breadth when gripping objects.

Regarding the measurements, the following data was included in - Table 1: age, sex, profession, personal background, mechanism of action, level of amputation according to the Merle classification, type and number of interventions,

Table 1 Compilation of patient data

\begin{tabular}{|c|c|c|c|c|c|c|c|c|c|c|c|c|c|}
\hline Gender & Age & Profession & $\begin{array}{l}\text { Merle } \\
\text { classif. }\end{array}$ & Mechanism & $\begin{array}{l}\text { External } \\
\text { fixator } \\
\text { days }\end{array}$ & Length & Comiss. & $\begin{array}{l}\text { Add } \\
\text { transpl }\end{array}$ & Graft & $\begin{array}{l}\text { Pinched } \\
\text { fingers }\end{array}$ & Incapacity & Satisfaction & Complications \\
\hline female & 28 & freelancer & 3 & elongation & 106 & 27 & YES & YES & & All & PPD & 3 & \\
\hline female & 40 & freelancer & 3 & flattening & 93 & 25 & YES & YES & & All & PPD & 4 & \\
\hline female & 56 & construction & 4 & elongation & 117 & 24 & YES & YES & YES & $\begin{array}{l}\text { 2nd, } \\
3 \text { rd, 4th }\end{array}$ & TPD & 3 & \\
\hline female & 26 & network & 3 & elongation & 112 & 23 & YES (3rd IQ) & YES & & All & PPD & 4 & $\begin{array}{l}\text { Closed } \\
\text { commissure }\end{array}$ \\
\hline female & 23 & & 3 & elongation & 108 & 28 & YES & YES & & All & no work & 4 & \\
\hline female & 55 & network & 3 & flattening & 89 & 22 & YES & NO & & All & PPD & 4 & \\
\hline female & 54 & & 3 & clean cut & 93 & 24 & YES (3rd IQ) & YES & & All & no work & 4 & $\begin{array}{l}\text { Closed } \\
\text { commissure }\end{array}$ \\
\hline female & 37 & freelancer & 4 & flattening & 127 & 26 & YES & YES & YES & $\begin{array}{l}\text { 2nd, } \\
3 \text { rd, 4th }\end{array}$ & TPD & 3 & \\
\hline female & 37 & network & 3 & elongation & 118 & 27 & YES (3rd IQ) & YES & & All & PPD & 4 & $\begin{array}{l}\text { Closed } \\
\text { commissure }\end{array}$ \\
\hline female & 24 & network & 4 & elongation & 140 & 32 & YES & NO & YES & $\begin{array}{l}\text { 2nd, } \\
3 \text { rd, 4th }\end{array}$ & TPD & 1 & Pin infection \\
\hline female & 61 & & 3 & clean cut & 86 & 21 & YES & NO & & $\begin{array}{l}\text { 2nd, } \\
\text { 3rd, 4th }\end{array}$ & no work & 3 & \\
\hline Male & 51 & network & 3 & elongation & 89 & 23 & YES & NO & & All & PPD & 4 & \\
\hline female & 40 & construction & 3 & elongation & 103 & 25 & YES & YES & & All & PPD & 3 & \\
\hline female & 43 & hotel staff & 3 & elongation & 97 & 23 & YES & YES & & All & PPD & 3 & \\
\hline female & 32 & construction & 4 & elongation & 132 & 30 & YES & YES & YES & All & PPD & 3 & $\begin{array}{l}\text { Pin } \\
\text { infection }\end{array}$ \\
\hline female & 26 & network & 4 & elongation & 102 & 26 & YES & NO & & $\begin{array}{l}\text { 2nd, } \\
\text { 3rd, 4th }\end{array}$ & TPD & 3 & \\
\hline female & 35 & freelancer & 2 & elongation & 95 & 25 & YES & NO & & All & PPD & 3 & $\begin{array}{l}\text { Flexión } \\
\text { muñón }\end{array}$ \\
\hline female & 37 & network & 4 & elongation & 108 & 28 & YES & YES & & All & PPD & 4 & \\
\hline female & 48 & construction & 2 & elongation & 120 & 24 & YES & YES & YES & $\begin{array}{l}\text { 2nd, } \\
\text { 3rd,4th }\end{array}$ & PPD & 2 & $\begin{array}{l}\text { Pin infection/ } \\
\text { Deformity } \\
\text { stump }\end{array}$ \\
\hline female & 44 & network & 2 & flattening & 83 & 24 & YES & YES (3rd IQ) & & All & $S$ & 4 & $\begin{array}{l}\text { Fracture } \\
\text { (deformity) }\end{array}$ \\
\hline female & 27 & construction & 3 & flattening & 91 & 27 & YES (3rd IQ) & YES & & All & TPD & 3 & $\begin{array}{l}\text { Closed } \\
\text { commissure }\end{array}$ \\
\hline female & 52 & - & 2 & flattening & 92 & 28 & YES & YES & & All & no work & 4 & \\
\hline male & 36 & - & 3 & elongation & 108 & 25 & YES & YES & & All & no work & 4 & \\
\hline
\end{tabular}

Abbreviations: Add transpl, adductor transplantation; B, scale; Comiss., comissuroplasty; IPPD, partial permanent disability; TPD, total permanent disability; S, economic compensation. 
elongation time (with an external fixator) and consolidation, millimeters lengthened, return to the workplace or classification of disability, grip ability and patient satisfaction on a scale of 1 to 4 ( $1=$ not at all satisfied; $2=$ unsatisfied; 3 = satisfied; and 4 = very satisfied).

For the statistical analysis, a database was created using the Statistical Package for the Social Sciences (SPSS, SPSS Inc., Chicago, Illinois, US) software, version 13.0. All variables and data collected in the study were added to this database.

Taking as events the elongation measured in millimeters and the total time of use of the fixator, the risk of removing the fixator (risk of elongation) was studied and calculated at 3 months and at 4 months as an indicator of the percentage of patients who achieved elongation during follow-up. The calculation of the mean elongation rate was based on the number of events detected during the follow-up (total elongated millimeters)/time at which the patients were at risk (days of use of the external fixator).

Continuous variables: "days of use of the fixator" and "elongated millimeters" were correlated with the ordinal "satisfaction" variable using the Pearson correlation coefficient, with a significance level of 0.05 and two-tailed test, since the data followed a normal distribution.

\section{Results}

We reviewed 23 patients with thumb amputations from the first phalanx to the metacarpal. Regarding the thenar muscles 4 patients were at level II, 13 at level III and 6 at level IV of the Merle classification. In 18 cases, the cause was an occupational accident, of which 17 patients were involved in heavy work (construction, metallurgy etc.). The mechanism of action was by section with clean cut only in two patients. The mean age of the sample was 39.6 years. One patient was an insulin-dependent diabetic, and 10 patients were smokers. Emergency replantation was initially attempted in 6 patients. These cases failed, generally due to being a limit indication because an aggressive trauma mechanism of action (-Fig. $\mathbf{1}$ ).
Although all patients had completed their procedures at 6 months, follow-up was continued for at least 12 months. All patients achieved consolidation and the minimum elongation previously set. The 23 metacarpal elongations had a mean of $25.5 \mathrm{~mm}$ (standard deviation [SD]: 0.54). The elongation time between surgeries was of 104.7 days on average (SD: 3.2). Six patients required a spongy bone graft in the second intervention due to the radiological presence of a weak bone callus.

The incidence analysis showed a risk of elongation (R) of $56.5 \%$ of the patients at the 3rd month, and of $95.7 \%$ of the patients at the 4 th month. The mean rate (I) of elongation was $0.2437 \mathrm{~mm}$ per day.

We found 10 complications, none of them serious. The most important one was the deformation of a metacarpal bone callus (-Figs. 2 and 3), which was not initially transposed, and was then resolved with surgical reduction, temporary fixation with Kirschner needles, and tendon transposition (-Figs. 4, 5 and 6). There were three mild infections from the external fixator pins or the externalized needles, which were solved with ATB or through withdrawal. The four patients who did not initially receive an enlargement of the commissure upon the removal of the fixator (because it was not considered necessary) had a retraction of said commissure, which was solved with a simple opening commissuroplasty (-Figs. 7 and 8), so all cases ended with this procedure. Two patients with level II amputations presented with a discrete attitude in the flexion of the residual stump of the proximal phalanx that had no clinical repercussion or need for treatment.

All patients were able to return to their everyday activities with minor limitations. Of the 18 occupational accidents, 13 workers remained in the same job with a variable financial compensation for the accident, and 5 were awarded total incapacity, but were able to perform other less demanding jobs.

In all cases, the patients showed a strong prehensile hand capable of handling a hammer-sized instrument, and with a fine pinch grip force in the second, third and fourth fingers. Only six patients failed to achieve a pinch grip force in the

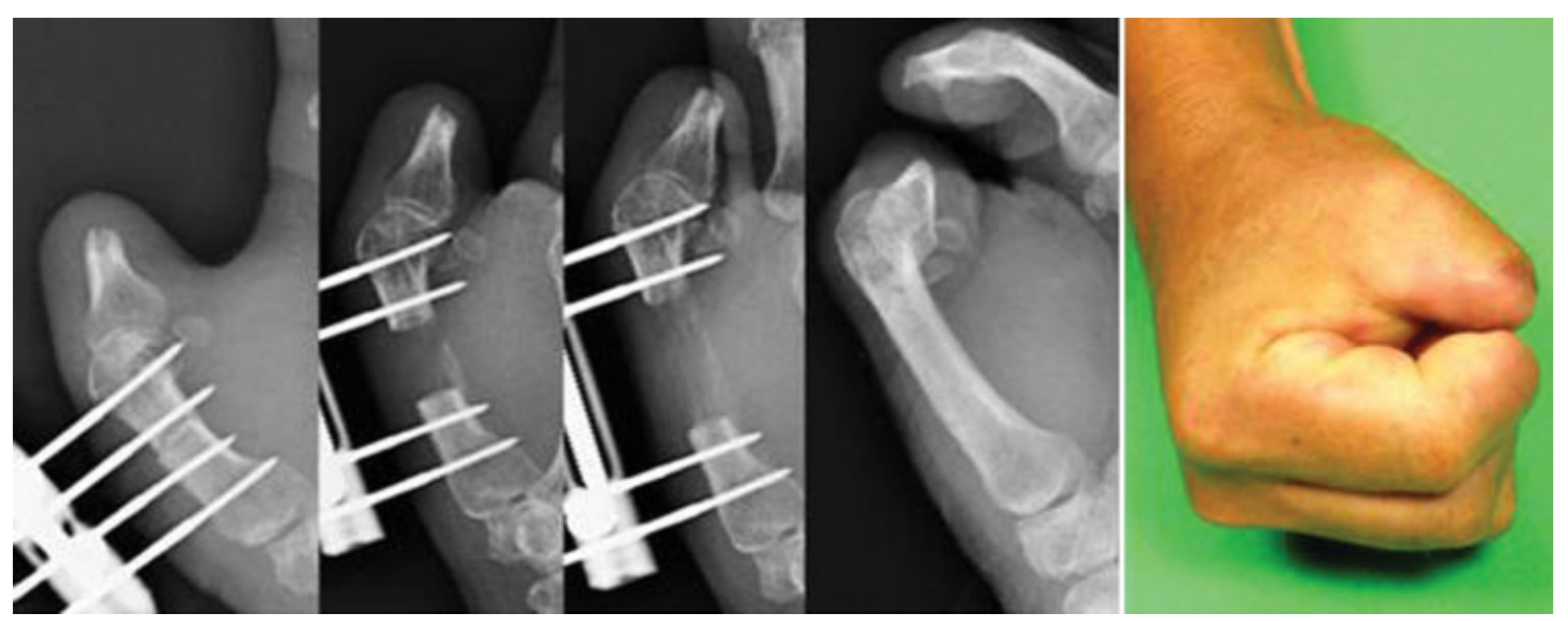

Fig. 1 Progressive callus distraction of the first metacarpal, achieving $24 \mathrm{~mm}$ and bone corticalization. The pinch force is functional despite the fact that the patient also suffered an amputation of the second finger in the middle phalanx. 


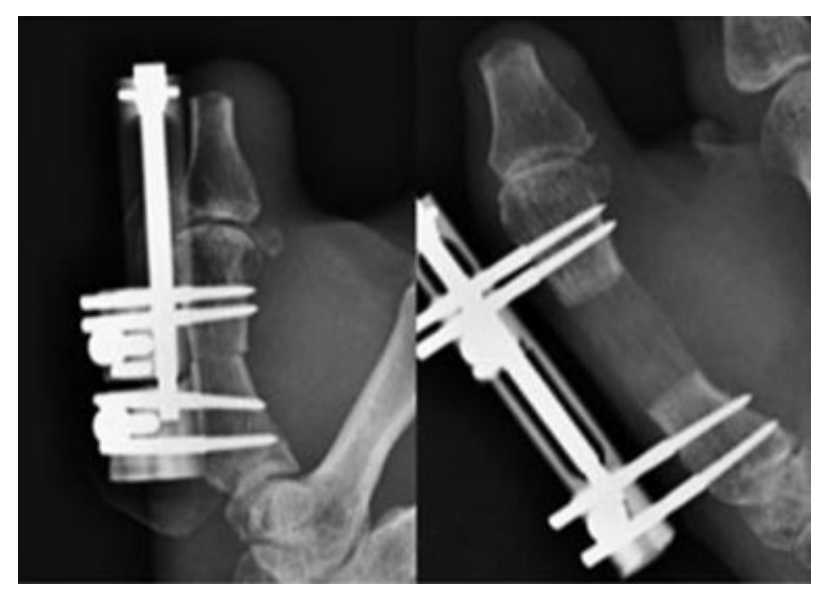

Fig. 2 Patient with 24-mm elongation after amputation due to failed replantation.

fifth finger without functional repercussion (-Fig. 9). Almost all patients, with the exception of two of them, were satisfied or very satisfied with the final result, and would undergo the same intervention again on the contralateral hand in the event of suffering the same accident.

When applying the Pearson correlation coefficient (-Table 2), a moderate $(r=-0.551)$ and statistically significant $(p=0.006)$ negative correlation was observed between satisfaction and days of use of the fixator (the more days, the lower the satisfaction). There was no statistically significant correlation between satisfaction and millimeters of elongation for $p=0.111$ ( - Fig. 10). There was also a statistically significant correlation between the number of days using the fixator and the elongated millimeters (-Fig. 11).

\section{Discussion}

Within our results, we would like to emphasize that in all cases we obtained the minimum forecast elongation (21 $\mathrm{mm}$ ) before starting each procedure. We obtained custom thumbs, which had lengths of more than $3 \mathrm{~cm}$, and were sensitive, functional and with a strong post for working. The process was well tolerated by the patients, who did not need to be immobilized. We obtained a positive correlation between the number of days using the fixator and the elongated millimeters, which was something logical that was expected.

The complications were easy to solve, and did not pose any obstacles to the achievement of the objectives. We would like to emphasize that all thumbs were functional, and although five patients did not return to their previous jobs, the final result was considered good from an occupational point of view.

The classic technique is usually performed in one or two interventions with grafting. The thumb is first stabilized with an external fixator, and then with needles or plates. We prefer elongation by callus distraction in two interventions. The difference between callus distraction and conventional elongations is that callus distraction prolongs the time spent using the fixator, but allows for early mobilization after its withdrawal, and avoids the use of grafts and Kirschner needles or plates, as there is no defect to be filled. It is the technique performed in children because of their osteogenic potential, ${ }^{10}$ but in adults it also gives good results if there is a slow elongation. However, we had to provide grafting in six cases as a preventive measure, upon assessing that ossification was radiologically insufficient. The time spent using the external fixator could have been prolonged to avoid grafting, but we considered it excessive to increase the days of the procedure, so as not to bother the patients. Tohl ${ }^{11}$ provided grafting in 5 of his 26 callus distractions on different fingers of the hand. This is an interesting line of debate between the advocates of rapid elongation with grafting and those who prefer callus distraction, which is safer but also slower.

The level of patient satisfaction was very high, but we would like to emphasize that it was greater in patients who spent less time using the fixator, as evidenced by the inverse correlation between the variables "satisfaction" and "fixator days". This confirms that it is not necessary to perform major elongations like those made in series such as Foucher's. ${ }^{12}$ On the other hand, there was no correlation between the patients' "satisfaction" and "elongation in millimeters", although, for the surgeon, the priority is usually to obtain

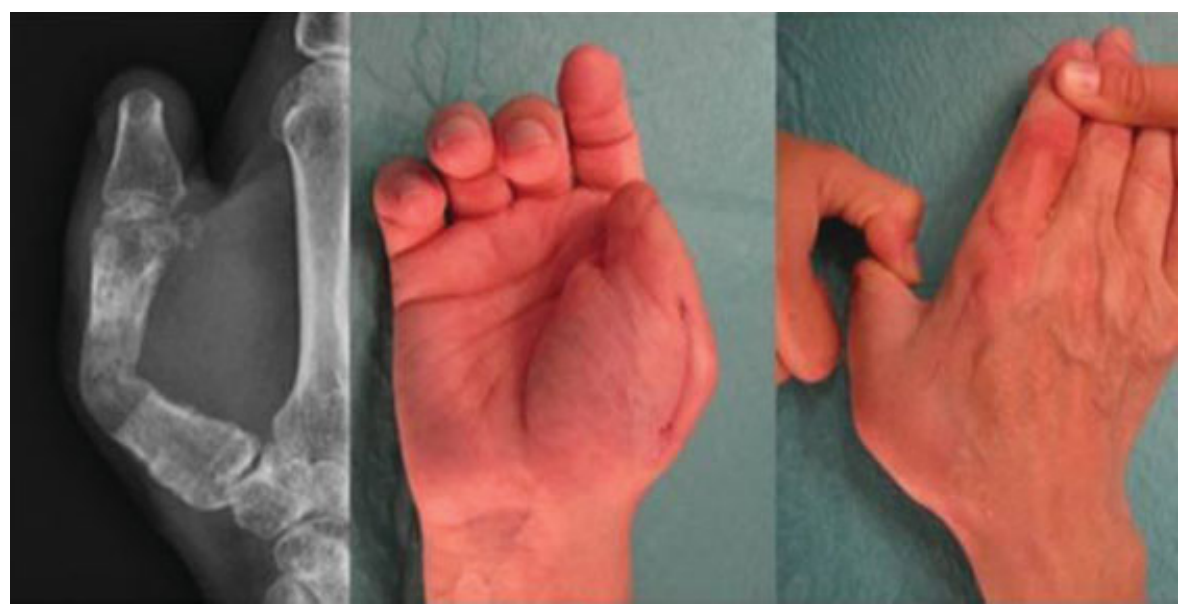

Fig. 3 Angled deformity of the metacarpal with closure of the commissure after removal of the fixator, due to not having performed adductor transposition. 


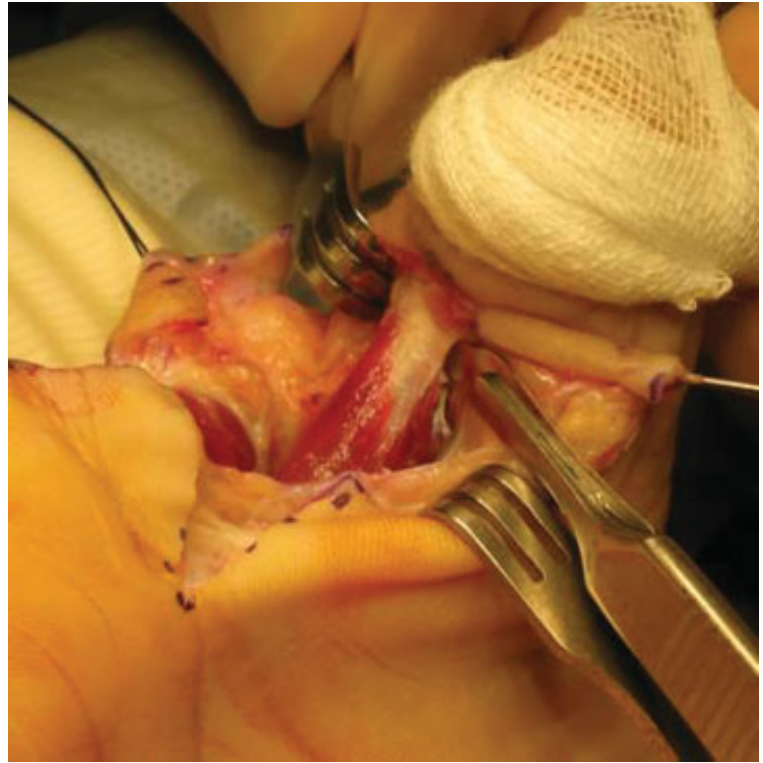

Fig. 4 Dissection and cut with scalpel of the distal insertion of the adductor muscle and tendon at the first commissure of the right hand. The stump of the thumb is being pulled by gauze.

the greatest thumb length possible This should make us reflect on the subjectivity of the concept of the success of a procedure, since it may be different for the doctor and for the patient.

One of the limitations of our study is the absence of scales of activity and quality of life such as the Disabilities of the Arm, Shoulder and Hand (DASH) score, or the Michigan Hand Outcome Questionnaire, which are very commonplace today. The most recent patients did complete them, but the oldest ones date back to the 1990s, and only a basic satisfaction questionnaire was available back then, so we used the same for all in the pursuit of uniformity.

There are cases described with elongations of up to $50 \mathrm{~mm}$ in the thumb, ${ }^{13}$ but we stopped elongation when

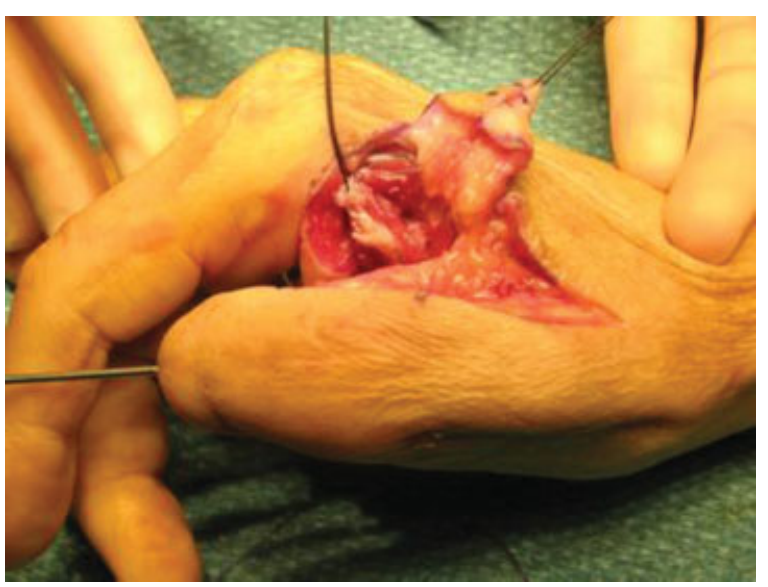

Fig. 5 Withdrawal of the aforementioned adductor with a thread. The cutaneous flap of the commissuroplasty is referenced to the right with another thread. The angulation of the metacarpal was resolved with a reduction and stabilization with needles.

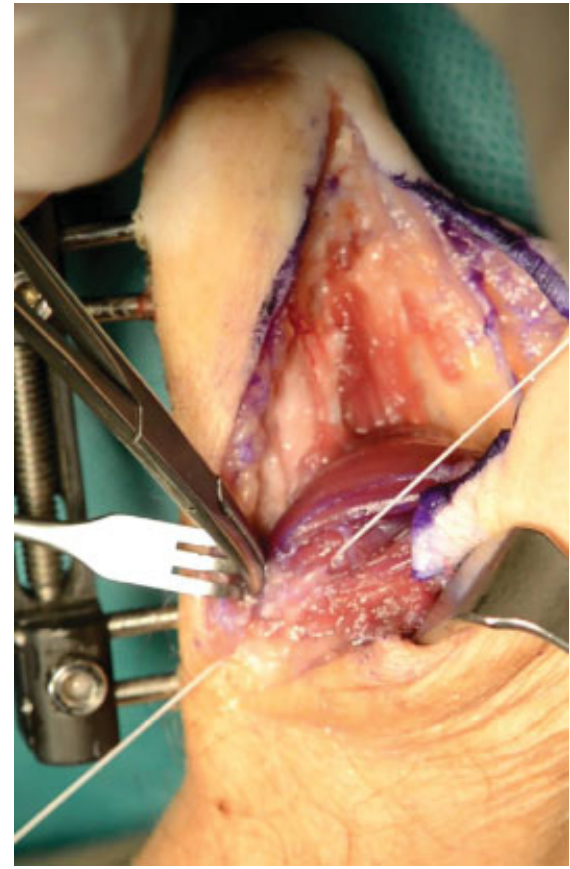

Fig. 6 Reinsertion of the adductor tendon in the proximal third of the metacarpal with a bone anchor and sutures in a different patient.

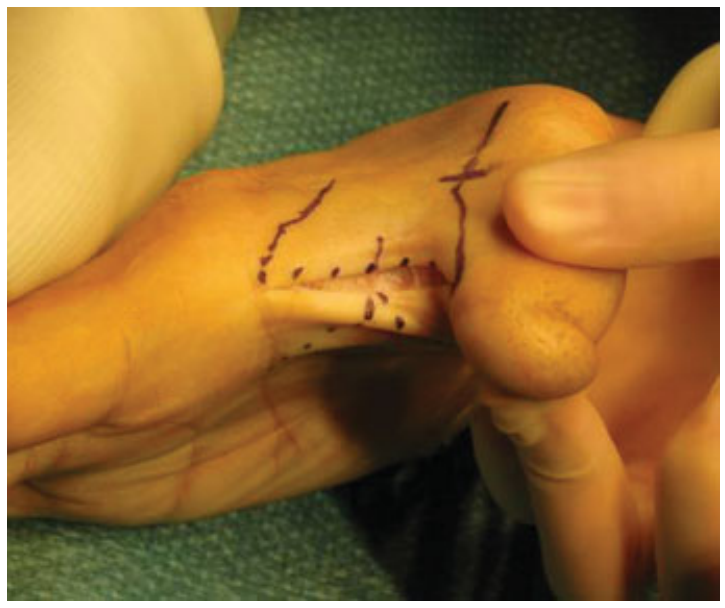

Fig. 7 Design of the commissuroplasty; this may be by means of zplasty, or double-opposing z-plasty, or "jumping man," as in this case.

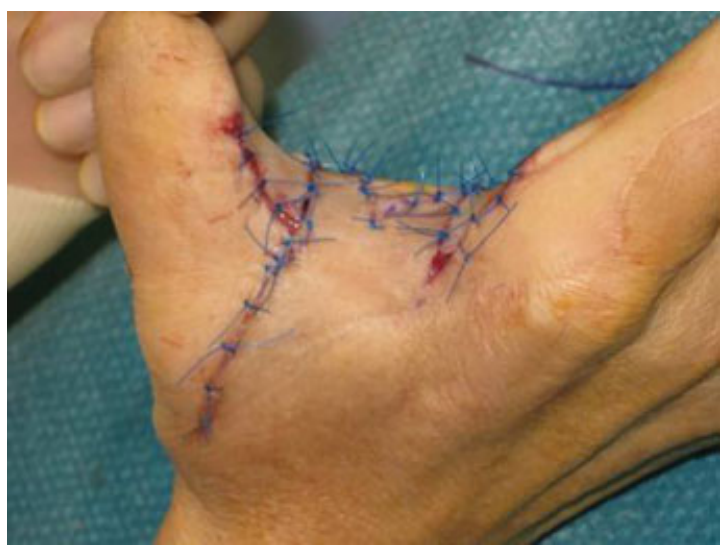

Fig. 8 Enlargement of the commissure after adductor transposition and commissuroplasty. 


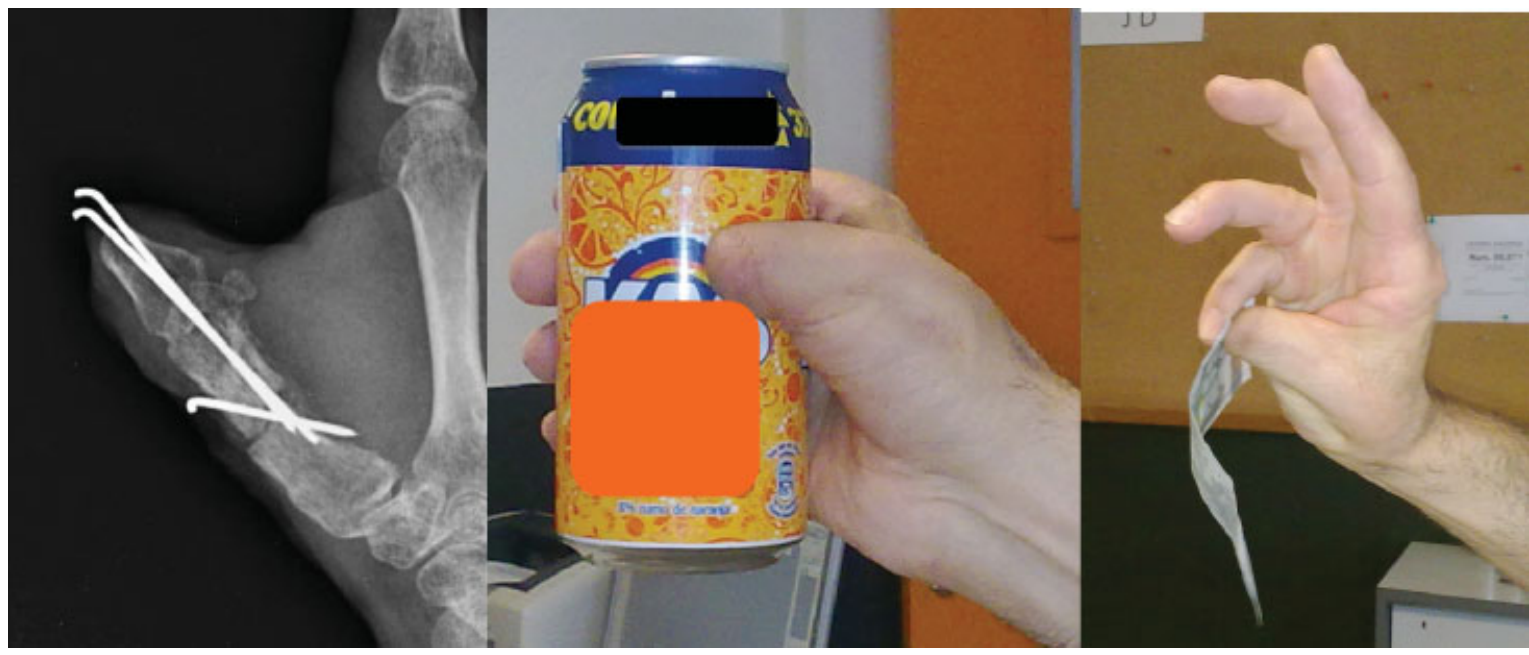

Fig. 9 Fixation with needles on the patient who suffered metacarpal angulation. The final clinical outcome was that the patient retained the ability to grip large objects and the pinch force with all the long fingers.

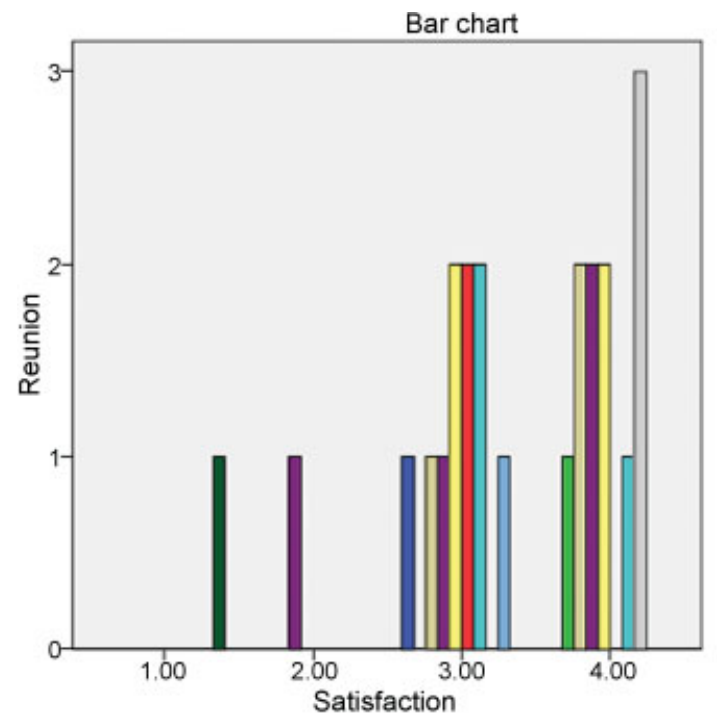

Fig. 10 Bar chart showing the distribution of patient satisfaction levels regarding elongation in millimeters.

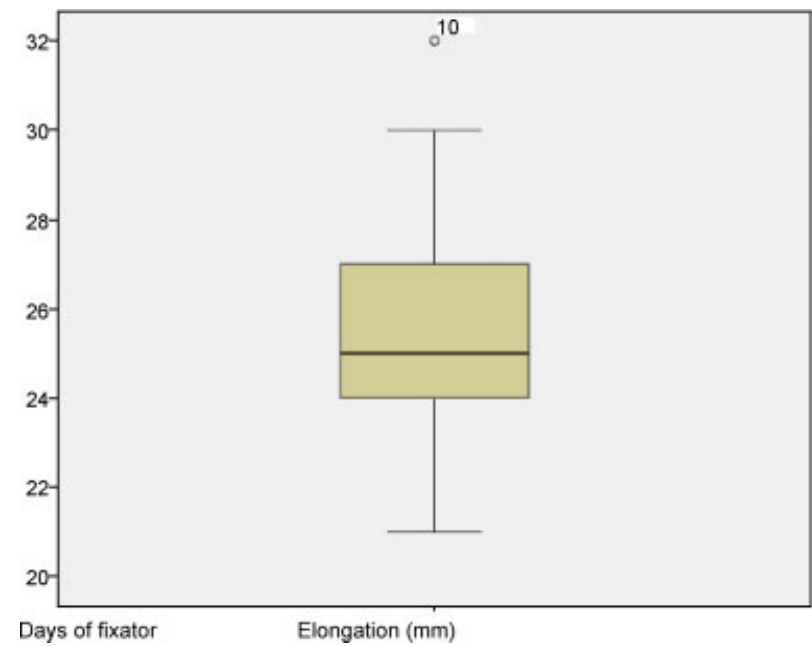

Fig. 11 Box diagram showing the relationship between the variables "days with fixator" and "elongation in millimeters."

Table 2 Correlation among the variables "satisfaction," "days of fixator" and "elongation in mm"

\begin{tabular}{|l|l|l|l|l|}
\hline Correlations & \multicolumn{5}{l|}{} \\
\hline \multirow{4}{*}{ Satisfaction } & Pearson correlation coefficient & Satisfaction & Days of fixator & Elongation (mm) \\
\cline { 2 - 5 } & Dig. (bilateral) & 1.00 & -0.551 & -0.341 \\
\cline { 2 - 5 } & $\mathrm{N}$ & 23 & 0.006 & 0.111 \\
\hline \multirow{5}{*}{ Days of fixator } & Pearson correlation coefficient & -0.551 & 23 & 23 \\
\cline { 2 - 5 } & Dig. (bilateral) & 0.006 & & 0.617 \\
\cline { 2 - 5 } & $\mathrm{N}$ & 23 & 23 & 0.002 \\
\hline \multirow{3}{*}{ Elongation (mm) } & Pearson correlation coefficient & -0.341 & 0.617 & 23 \\
\cline { 2 - 5 } & Dig. (bilateral) & 0.111 & 0.002 & 1.00 \\
\cline { 2 - 5 } & $\mathrm{N}$ & 23 & 23 & 23 \\
\hline
\end{tabular}

Abbreviations: Dig, significative; N, numbers. 
we considered that the length was sufficiently functional and, therefore, we shortened the time of use of the external fixator and the time spent off work. With callus distraction, we had to wait until the fourth month to remove the fixator in $95.7 \%$ of the patients, since by the third month only $56.5 \%$ had achieved adequate length and ossification.

Studies such as Foucher's ${ }^{12}$ have a shorter elongation time (72.6 days) with a distraction rate of 2-3 $\mathrm{mm}$ per day and no obvious radiographic signs of ossification, which forces the need for bone grafting. Most of the published series focus on rapid elongations with grafting, but there are other series that perform elongations by callus distraction, presenting elongation lengths and external fixator times similar to ours: for example, Toh ${ }^{11}$ reached $17 \mathrm{~mm}$ and an average of 96 days in the 17 cases that did not suffer any complications, and $19 \mathrm{~mm}$ and 158 days in the 9 that did show some sort of problem. Seitz and Froimson ${ }^{14}$ published 14 elongations between 20 and $35 \mathrm{~mm}$ at a slow growth of $0.25 \mathrm{~mm} 4$ times a day on different fingers in which the etiology was traumatic. Capdevila and Nualart ${ }^{15}$ performed 16 procedures for 12 weeks on average, with an average elongation of $15 \mathrm{~mm}$, but, like the previous authors, they acted on any finger of the hand, and combined traumatic with congenital etiology (hypoplasia). The only study that, like ours, is limited to callus distraction after amputations of the first metacarpal is that of Heitmann and Levin, ${ }^{16}$ who obtained an average growth of $28 \mathrm{~mm}$ and a consolidation of the metacarpal in 155 days on average (although the distraction lasted only 57 days); with the only differences being a lower number of cases (7), and the fact that they did not perform the adductor transposition.

The complications were easy to solve, being similar to other studies. Matev ${ }^{17}$ reported 2 infections by pins, 2 bone deformities, and 3 flexion contractures of the metacarpophalangeal joint in 83 patients. It is interesting to note that we also saw a fracture with plastic deformity of the metacarpal, although in our case it did not happen due to an early removal of the fixator, as happened to Matev ${ }^{17}$ and Foucher, ${ }^{12}$ but due to not having transposed the adductor. When performing a slower elongation, it is not necessary to add a Kirschner needle to the fixator to prevent diaphyseal angulation. Capdevila ${ }^{15}$ registered 3 infections by pins, 1 deformity of the bone callus, and 2 cases of the fixator loosening due to osteolysis in 16 procedures. Seitz and Froimson ${ }^{14}$ did not observe any major complications. In the 26 fingers intervened in Toh's series, ${ }^{11}$ there were 3 early consolidations, 2 superficial infections, 4 closures of the first commissure resolved with z-plasty, 2 metacarpophalangeal joints with flexion attitude, and 4 fractures of the bone callus. Heitmann and Levin ${ }^{16}$ reported 3 minor complications, and 3 out of the 7 patients had to find new jobs.

The disadvantages of callus deflection are relative. It forces a second surgical intervention, but this is commonplace in any type of elongation. The duration of the process can be extended to 5 or 6 months if the onset of the callus is slow, ${ }^{16}$ but recovery is rapid after the second surgical intervention, because mobility is the same as the previous one, since it depends on the trapeziometacarpal joint, which must be free. Sensitivity is good, as the skin is the same as the one on the stump of the thumb itself. Aesthetically, the thumbs are usually well tolerated, despite the absence of a nail, which in the workplace is not an inconvenience. Seitz and Froimson ${ }^{14}$ found that a slow elongation rate was associated with greater comfort, with patients being able to perform everyday activities during the elongation period.

From our experience, we consider that commissuroplasty and adductor transposition should always be added to the second surgical intervention, together with the withdrawal of the mini-fixator even in cases in which it may seem unnecessary, since this would prevent deformities of the metacarpal, stop the closure of the first commissure, and save the patient the need for a third surgical intervention.

We also observed that in the elongations in level II Merle amputations (in which the base of the proximal phalanx is conserved), it is advisable to block the metacarpophalangeal joint with a fully extended Kirschner needle to prevent the flexion of the joint due to the pressure caused by the growth of the metacarpal.

\section{Conclusions}

Drawing on our experience, we found that elongation of the first metacarpal by callus distraction is a reproducible procedure, with few complications and easy to solve, and it is a good choice not only in situations in which other more complex techniques are not appropriate, but also for any patient with a thumb amputation retaining the proximal half of the metacarpal. It is a more basic concept than the transfer of toes to the hand, but we believe that it should not fall into disuse. It can solve difficult situations in a relatively simple way and with a high degree of satisfaction, since the patients rated the functionality and comfort of the process higher than the achievement of a longer elongation. It would be desirable to undertake comparative studies between the different thumb elongation techniques and the different types of secondary reconstruction, but the presence of different levels of amputation and the limited incidence of cases make it difficult for this to be performed.

\section{References}

1 Real Decreto. 1856/2009, de 4 de diciembre, de procedimiento para el reconocimiento, declaración y calificación del grado de discapacidad, y por el que se modifica el Real Decreto 1971/1999, de 23 de diciembre. Boletín Oficial del Estado de 26 de diciembre de 2009. 311: 110413-110415. http://www.boe.es/boe/dias/ 2009/12/26/pdfs/BOE-A-2009-20891.pdf (último acceso 10 de febrero de 2017).

2 Baumeister S, Menke H, Wittemann M, Germann G. Functional outcome after the Moberg advancement flap in the thumb. J Hand Surg Am 2002;27(01):105-114

3 Chase RA. An alternate to pollicization in subtotal thumb reconstruction. Plast Reconstr Surg 1969;44(05):421-430

4 Lister $\mathrm{G}$. The choice of procedure following thumb amputation. Clin Orthop Relat Res 1985;(195):45-51

5 Adani R, Corain M, Tarallo L, Fiacchi F. Alternative method for thumb reconstruction. Combination of 2 techniques: metacarpal 
lengthening and mini wraparound transfer. J Hand Surg Am 2013; 38(05):1006-1011

6 Del Piñal F, Pennazzato D, Urrutia E. Primary thumb reconstruction in a mutilated hand. Hand Clin 2016;32(04):519-531

7 Del Piñal F, García-Bernal FJ, Thams C, Studer A, Regalado J. Informe sobre el transplante de 250 dedos del pie a la mano consecutivos. Indicaciones, resultados, fracasos y nuevas aplicaciones. Rev Esp Cir Ortop Traumatol 2011;55(04):257-262

8 Matev IB. Thumb reconstruction through metacarpal bone lengthening. J Hand Surg Am 1980;5(05):482-487

9 Merle M. Reconstrucción del pulgar. En: Merle M, Dautel G, Loda G. Mano traumática. Cirugía secundaria. Muñeca traumática. Barcelona: Masson; 1996:249-261

10 Dana C, Auregan JC, Salon A, Guero S, Glorion C, Pannier S. Metacarpal lengthening in children: comparison of three different techniques in 15 consecutive cases. J Hand Surg Eur 2016;42(01):51-56
11 Toh S, Narita S, Arai K, Nakashima K, Tsubo K. Distraction lengthening by callotasis in the hand. J Bone Joint Surg $\mathrm{Br}$ 2002;84(02):205-210

12 Foucher G, Lamas C, Mir X. Reconstrucción digital según técnica de Matev. Estudio de 45 casos. Rev Iberoam Cir Mano 2000; 27(57):31-39

13 Matev I. Thumb metacarpal lengthening. Tech Hand Up Extrem Surg 2003;7(04):157-163

14 Seitz WH Jr, Froimson AI. Digital lengthening using the callotasis technique. Orthopedics 1995;18(02):129-138

15 Capdevila Leonori R, Nualard Hernández L. Alargamiento progresivo de los huesos de las manos mediante callotasis. Rev Esp Cir Ortop Traumatol 1999;43:23-28

16 Heitmann C, Levin LS. Distraction lengthening of thumb metacarpal. J Hand Surg [Br] 2004;29(01):71-75

17 Matev IB. Progressive lengthening. En: G. Foucher. Reconstructive surgery in hand mutilation. London: Martin Dunitz; 1997:23-28 